\title{
An Assessment of Human Resource Utilization on Organizational Growth and Development of Adamawa State Polytechnic Yola
}

\section{Francis $\mathrm{F}^{*}$}

Department of Business Management Education, Adamawa State Polytechnic, P M B 2146 Yola, Nigeria

\begin{abstract}
It has become imperative for management of organizations to re-evaluate the position or the relevance of workers. Maximum productivity level cannot be achieved, unless the essential material resources are available, even if an organization has gotten all the money and materials it needs. This study assesses the impact of human resource utilization on organizational growth and development of State Polytechnic Yola. The target population of the study mainly consists of 842 academic and non-academic staff of the SPY. The data for this study was sourced through the use of structured questionnaire distributed to the staff of SPY. A total of 271 questionnaires were distributed but 253 were successfully retrieved and analyzed. The study employed descriptive statistics, multiple regression technique in estimating the effects of human resource management practice on organizational growth and development in SPY, Cronbach Alpha were used to test for reliability, correlation coefficient was also used to test the extent to which human resource utilization relate to organizational growth. The findings revealed that human resource utilization, recruitment and selection, manpower training and development and staff welfare/health, safety have positive impact of organizational growth and development of SPY. Conclusively, human resource utilization has positively and significantly impacted on the growth and development of SPY. The study recommended that since human resources utilization is a line activity, therefore, organizations should ensure that there a functional human resources department that will always be responsive to the manpower needs of the organizations. Management should at all times employ professional human resources personnel to handle and provide the required and efficient human resources needs of the organizations. It further recommended that since employees' productivity is significantly and positively varies with utilization of human resources in organizations, as such management should ensure that there are programmes to encourage and improve the employees' productivity and lastly, the management of organizations through the human resources department should expand and improve the recruitment, selection and placement process in order to get the best manpower to the right position at the right time.
\end{abstract}

Keywords: Human resource; Utilization; Organizational growth; Development

\section{Introduction}

The greatest asset of any organization is its human resources that ensure that achievement of the company's goal and objective. (Source: Human resource Article 2012). It is unfortunate that most company's organization have neglected the development and management of their chief asset which is human resource (human resource Article 2012). According to Susan [1] human Resource Management is the function within an organization that focused on recruitment of, management of, and providing direction for the people who work in the organization. Human resource (HR) managers have to organize and manage human resources in order to add value and enhance productivity. One of the ways for an organization to succeed in a turbulent business environment is not just to adjust to customer needs, but to have intelligent, educated and creative employee. Human resource knowledge and skills become the basis for development of organizational competitive advantages on modern business landscape. Efficient human resource (HR) managers hire individuals that will help an organization achieve its strategic goals. A firm's employees can provide a unique source of competitive advantage that is difficult for its competitors to replicate. Effective human resource management enables employees to contribute effectively and productivity to the overall company direction and the accomplishment of the organization's goal and objective [1]. The term human resource utilization here simply means the effective and efficient use of human resource in an organization in order to achieve desired growth and development of any organization, and to avoid wastage of manpower. The effective utilization of human resource is seen as key factor to growth and development of an organization in this contemporary world faced with challenges such as globalization, tribalism, corruption and mismanagement.

Susan [1] went further to explain that human resources exist within people and consists of a person's potential ability as well as critical knowledge, skill and other personal characteristics which include personality factors (attitudes), aptitudes, physical and mental traits needed to perform the job. Human resource management has the opportunity to enable organizations to survive, grow, be competitive and profitable [2]. The success and continuity of any organization is hinged on the active Human Resource Management, to ensure that the employee irrespective of cadre actively participate towards organizational goals.

According to Susan [1] human Resource Management is the function within an organization that focused on recruitment of, management of, and providing direction for the people who work in the organization. It is also a strategic and comprehensive approach of managing people and the work place culture and environment

*Corresponding author: Francis F, Department of Business Management Education, Adamawa State Polytechnic, P M B 2146 Yola, Nigeria, Tel: +2348066030046; E-mail: francisfelix30@yahoo.com

Received October 17, 2018; Accepted October 31, 2018; Published November 05, 2018

Citation: Francis F (2018) An Assessment of Human Resource Utilization on Organizational Growth and Development of Adamawa State Polytechnic Yola. Arts Social Sci J 9: 419. doi: 10.4172/2151-6200.1000419

Copyright: (๑) 2018 Francis F. This is an open-access article distributed under the terms of the Creative Commons Attribution License, which permits unrestricted use, distribution, and reproduction in any medium, provided the original author and source are credited. 
[1]. Effective Human resource management enables employees to contribute effectively and productivity to the overall company direction and the accomplishment of the organization's goals and objectives [1].

Human resource management is administrative activities associated with human resources planning, recruitment, selection, orientation, training, appraisal, motivation and also a functions within an organization that focuses on people (Wikipedia, 2012). According to Wikipedia, Human resources is the set of individuals who make up the work force of an organization. Human resource management encompassed activities designed to provide for and co-ordinates, all human element within the organization. This will ensure its stable continuity and achievement. The human personnel element represents one of the company's largest investments [1].

According to Wikipedia 2012, Human resource is also known as human capital for utilization, harnessing, development and direction of a nation's objective. It is also all about the formation of values and attitude. Therefore, human resources development is a universal norms and not a view concept. There is no industry, firm, organization, business enterprises, nation etc. that can boost a political, economic and social stability, quality product and profitability without adequate human resources in place.

There are various problems that are associated with the Impact of Human Resource utilization on Organizational growth and development. It has become imperative for management of organizations to re-evaluate the position or the relevance of workers. Maximum productivity level cannot be achieved unless the essential material resources are available, even if an organization has gotten all the money and materials it needs, it must still manage the materials effectively for optimal productivity. The research directs its analytical tools towards problems associated with growth and development of State Polytechnic Yola in the utilization of its human resource. So in its own effective and efficient management is necessary and important in any given organizations, the human resources management should increase effects on training of its employee, and also a need to encourage staff with allowances.

However, this study is being carried out to assess the impact of human resource utilization on organizational growth and development in State Polytechnic, Yola.

The main objective of this study is to assess the impact of human resource utilization on organizational growth and development in State Polytechnic Yola, Adamawa state, to examine the impact to which human resource is effectively and efficiently utilized, to assess the impact of manpower training and development in the utilization on organizational growth and development. To identify the impact of recruitment/selection in the utilization of human resource management, and to identify the impact of Staff welfare/ health and safety of the employees towards human resource utilization for growth and development.

\section{Research Hypotheses}

$\mathrm{H}_{01}$ : Efficient human resource utilization impact negatively on the organizational growth in State Polytechnic Yola.

$\mathrm{H}_{02}$ : Manpower training and development does not have any positive significant relationship with human resource utilization in State Polytechnic Yola.

Ho3: There is no significant factor militating against effective utilization of resources.
$\mathrm{H}_{04}$ : Ineffective personnel recruitment, selection and placement do not cause any negative effect on the utilization of human resources.

Ho5: Staff Health, Safety and welfare has no significant on organization growth and development.

\section{Literature Review}

\section{Conceptual issues}

The critical nature of human is an organization as a factor of success or failure of management is put as follows. All activities in any enterprise are initiated and determined by persons who make up the institution plant, office, of all task of management, managing the human component is the central and most important task because all else depends on how it is done. Human resource management is administrative activities associated with human resource planning, recruitment, selection, orientation, training, appraisal, motivation and also functions within an organization that focuses on people (Wikipedia 2012). According to Wikipedia, human resource is the set of individual who make up the work force of an organization. Human resource management encompassed activities designed to provide for and coordinates, all human element within the organization. This will ensure stable, continuity and achievement. And this will lead to growth and development of the organization. The human personnel element represents one of the company's largest investments [1].

Consequently, organization should prioritize the development of the human element to maximize talents, skills and ability which will automatically reflect on the company's profit. It pre-supposes that we do need people in order to form a business which that no business can exist without people. Even a computer auto-mental machine factory has to employ some people, though a conventional plant with similar capacity might require people. There arises the need for proper planning of these people employed otherwise known as "Manpower planning" (source; e-How contributing writer). Most organization does not have plans for the development of their members of staff. Once these people are recruited, the organization does not orientate them; neither do they train them to acquire other modern skills to improve their talent and education qualification they came with.

Organization need to plan and equip their labour force which will boost quality product and profit making of their organization. Human resource development makes sure that manpower planning in an organization is not static but an ongoing process (source; Human resource article, 2009). If focuses on raising productivity through improved quality, efficiency, lost reduction and enabling customers concentrate on their core business activities. According to Wikipedia 2012, human resource is also known as human capital for utilization harnessing development and direction of a nation objective. There is no industry, firm, organization, business enterprise etc. that can boost political, economic and social stability, quality product and profitability without proper utilization of human resources in place.

\section{Concept of human resource management}

Human resource management is the function within an organization that focuses on recruitment of employees and providing direction for the people who work in an organization. Human Resource management can also be performed by line manager. Human resource management is the organizational function that deals with issues related to people such as compensation, hiring, performance management, organization development, safety, wellness, benefits, employee motivation, communication, administration and training [1]. Human 
resource management is also a strategic and comprehensive approach to managing people and the work place, culture and environment. Effective Human resource management enables employees to contribute effectively and productively to the overall company direction and the accomplishment of the organization's goals and objectives [1].

A company is able to better manage its intellectual capital and improve organizational performance by properly implementing a Human Resources Management System (HRMS) [2]. The advent of "knowledge -intensive era" has turned human resources into a company's most important core resource, and an appropriately implemented HRMS helps an organization develop internal human resources, build competitiveness intellectual capital, and eventually buster its operating performance and enterprise value [3]. Competitive advantage for the organization lies not just in differentiating a product or service or in becoming the low cost leader but is also being able to tap the company's special skills or core competencies and rapidly respond to customer's needs and competitor's moves [4]. Human resources management can play a role in identifying and analyzing external opportunities and threats that may be crucial to the company's success. It is in a unique position to supply competitive intelligence that may be useful in the strategic planning process.

The activities range from attracting high quality employees, placing them in appropriate position, training them to work in the firm's specific way, and motivating them to devote more, if enough attentions are not being paid to coordination of human resources, the organizational effectiveness is likely to be decreased [5]. An excellent employee might find it quite difficult to achieve high performance without good training compatible with organizational goals and the work itself. Similarly, a lack of motivation for well trained employees may be linked with the performing below their potentials. It logically follows that adoption of effective technical HRM activities is a key to implementing a set of internally consistent human resources practices [6]. In other words, effective technical human resource activities are necessary for accomplishing the partial goal of HRM.

Importance of human resources planning: According to Kenneth [7] no doubt, human resources planning is to immense importance to an organization whether private or public. The importance of human resource planning can be seen from the angle of trying to avoid excessive overtime situation because of the insufficient workers in an organization. Other reason to avoid over staffing which might create redundancy and de-motivation and drain on companies or organizations profit. To avoid loss of business opportunities this can result to lack of appropriate manpower. Also the techniques of human resource planning can be used in reducing mobility of labor so that people are likely to remain with the organization. It can also ease the difficult of recruitment, because recruitment as we know is costly and time consuming activity. Similarly delay in recruitment have tendency of destroying staff morale.

To Ogbodo [8], human resource planning also help to reduce personnel cost by helping management to anticipate surplus or shortage of human resource and to correct the imbalance before they become unimaginable and expensive to both organization and employers. It also provides a better basis for planning employee's development in term of job performance. Human resources planning help improve overall business process, this is because the success marketing production, finance in any organization rest on human resources planning. It also helps the organization to cope with challenges in competition forces, technology, government regulation policies. It encourages planning which involves top management evaluation of environment, it also provide vital information for designing and implementation of personnel functions such as recruitment. Lastly it creates awareness on importance of sound human resource management throughout the level of the organization.

Human resources utilization: To Ogbodo [8] the term human resources utilization refers to a means whereby managers are able to employ the right workers for the right job, train and develop the workers so that they contribute meaningfully to pursue the organizational goal to avoid wastage. Also to maintain the productive work force through various retention initiative such as motivation in other to continuously sustain productivity at a minimum cost and maximum output.

Recruitment and selection in organisation: Qureshi and Ramay [9] noted that HR practices are positively correlated with employee's performance whereas selection and training have more effecting on performance than other practices. Chand and Katou [10] demonstrated that recruitment and selection, strongly correlate with profitability and suggests that management of an organization must focus on these HRM practices (recruitment and selection) resulting in an improved organizational profit. According to Bratton and Gold [11], recruitment is 'the process of generating a pool of capable people to apply to an organization for employment' and selection is 'the process by which managers and others use specific instruments to choose from a pool of applicants the person(s) most likely to succeed in the job(s), given management goals and legal requirements. Companies use good selectivity in the hiring process to ensure that they get the right skilled and qualified people for the right job [12,13]. Budd and Bhave [14] maintained that the recruitment exercises remain the power of the management in any organization to ensure proper starting of employee in their firms. Recruitment remains one of the ways to get things right in the firm by ensuring that the most competent and qualified applicant gets the job.

Training and development: Training and development are the formal activities undertaken by an organization to help employees acquire the skills and experience needed to perform current or future jobs [15]. In general, training and development activities are designed to help employees continue to make positive contributions in the form of good performance by obtaining new knowledge, skills and abilities [16]. Mookherjee [17] expressed that on-the-job training is one of the commonly used type of training. It is also an effective method of training the operative personnel. In this method, the worker is trained at his/her work-place. Also, Mookherjee [17] expressed further that off-the-job-training is a type of training that can be given in a number of ways. Off-the-job-training consist of lectures, conferences, group discussion, case studies, and programmers instructions, etc. This method is generally used by government and public enterprise.

According to Ojo [18] training is the act of increasing the knowledge and skill of an employee for doing a particular job, irrespective of the years spent so far in the service or the qualification attainment of the workers, the trends in the services will always protrude towards development in the societies and changes in tastes of customers, which organization must promptly responded to by training their employees with latest techniques, tools and approaches.

Peretomode [19] pointed out that training is a planned organizational efforts or activities concerned with helping an employee acquire specific and immediately usable skills, knowledge, concepts, attitudes and behavior to enable him or her perform more efficiently and effectively on his present job.

Performance appraisal in human resources: The measurement of 
employees' performance allows the company to provide compensation fairly to the deserving individuals according to certain predetermined criteria like employee competency, teamwork ability, initiative, soft skills and ethics [20].

Performance appraisal is a process used to identify, measure, evaluate, improve, encourage and reward employees for their performance [15] Specifically, performance appraisal is a formal system used by an organization to periodically review and evaluate employees' performance. In other words, performance appraisal is the process of evaluating how well employees perform their tasks compared with a set of standards or organization's expectations.

Internal communication enhances a number of important bottom line outcomes for an organization including increased employee productivity and organizational profitability [21]. Internal communication boosts productivity by streamlining employees' roles and duties in organizations [22]. Employee commitment, productivity, and retention can be improved with performance appraisal system. Brown et al. [23] states that possibility of performance appraisal is enhanced by complementary human resource management practices like formal training and incentive pay and performance appraisal leads to greater influence of employees' productivity.

Compensation and reward system in human resources: Bratton and Gold [11] state that reward refers to 'all of the monetary, nonmonetary and psychological payments that an organization provide for its employees in exchange for the work they perform either as teamwork, units, department or individual'. Motivating employees through a good reward system constitutes a difficult and challenging task for general managers as it can positively affect employees' behavior toward their jobs and increase their commitment and thus their performance. Bratton and Gold [11] states that reward strategies are an important part of an organization's human resources strategy and should be bundled with other human resources strategies so that they complement and reinforce one another. Golden and Veiga [24] and Huselid et al. [13] respective found in their studies that motivation through a good reward system can lead to an increase in employees' productivity as well as improve their commitment towards organizational goals.

Planning as human resource practice: Planning the workforce needs of any company is very critical and important especially in the rapid changes in external market demands. Koch and McGrath (2008) found a positive relationship between human resources planning and labor productivity. According to Kaiser [4] half a career is an individually perceived sequence of attitudes and behaviors associated with work related experiences and activities over the span of the person's life. According to Werner and DeSimone [25], human resource planning helps companies predict how changes in their strategy will affect their human resource needs. Planning comes ahead of other organization activities, while planning, a firm may realize that some particular employee is being underused or discover that onus of activities are swivel towards particular units, group or individual within organization. Such discovery will immediately calls for task redistribution to avert the danger of "one man fall, all firm fall". In short, a well-planned organization cannot afford to build the firm around one staff.

Participation and involvement in human resources: Companies intending to gain a sustained competitive advantage should help their employees participate actively including aspect like decision-making processes and involve them in the day-to-day problems solving in organization. Putting in place employee involvement program afford employees with opportunities to reflect their own attitudes and work experiences, as well as their own hopes for the future [11]. Grant [26] states that high-involvement practices may influence organizational performance and that employees' involvement in problem-solving and self-directed teams may increase autonomy and satisfaction.

\section{Methodology}

For the purpose of this study, the researcher adopts the survey research design. Survey research design is one in which relative elements of the population with a common attributes are chosen with a view to representing the entire population. Moreover, the outcome of the studied and selected group is normally adequate and sufficient, which is used as a basis for generalization.

The population to be surveyed must be clearly defined before any research can be carried out; the populations of the study consist of both academic and non-academic staff of State Polytechnic Yola. In this study therefore, the population includes 465 non Academic Staff and 377 academic staff in the SPY. Therefore, the total population of the study is 842 .

The sample size of this study will be determine using Yamane, since Yamane is to determine finite population. Yamane [27] states the formula for determining the sample of the study as follow:

$$
n=\frac{N}{1+N(e)^{2}}
$$

Where:

$\mathrm{n}=$ Sample size

$\mathrm{N}=$ Total population

$\mathrm{e}=$ Margin of error disturbance

Therefore;

Given that $\mathrm{N}=842$ (as stated above), and e is assumed 5\% Then sample size:

$$
n=\frac{842}{1+842(0.05)^{2}}=271
$$

The researcher used non Probability sampling technique, a purposive sampling was employed. Purposive sampling is the process were the characteristics of the subject grant it qualification to be included in the sample. He further claimed that purposive sampling is relatively cheaper and easier and ensures that only those elements that are relevant to the research are included, therefore both academic and non-academic staff were purposively selected and sample size still drawn from them using the purposive sampling technique.

The method of data collection was questionnaire. The researcher administered structured and closed ended questionnaire to the respondents. The study used self-administered questionnaire. Mugenda [28] observed that, questionnaires are frequently used in quantitative social research.

The researcher used a descriptive method in the analysis of data, the instrument was in tables and simple percentage, and the researcher used descriptive method because, it provides empirical analysis and allow easy interpretation of the results. Multiple regression will be used to analyze and test the hypotheses $[29,30]$.

\section{Model Specification}

$$
\mathrm{Y}=\alpha+\beta 1 \mathrm{X} 1+\beta 2 \mathrm{X} 2+\beta 3 \mathrm{X} 3+\beta 4 \mathrm{X} 4+\beta 5 \mathrm{X} 5+\mathrm{ei}
$$


Training/Development

$\beta 3=$ Compensation $/$ Reward System

$\mathrm{X} 3=$ coefficientCompensation/Reward System

$\beta 4=$ Performance Management

$\mathrm{X} 4=$ coefficient of performance management

$\beta 5=$ Employee health safety/Welfare

X5=coefficient ofEmployee health safety/Welfare

$\mathrm{Y}=$ Employee performance

$\beta 1=$ Recruitment $/$ Selection

$\mathrm{X} 1=$ coefficient of Recruitment /Selection

$\beta 2=$ Manpower Training/Development X2=coefficientManpower.

\section{Data Presentation and Analysis}

\section{Analysis on impact of human resource utilization on Adama- wa state polytechnic Yola}

Table 1 above presents the summary results for the impact of human resource utilization on organizational growth and development in State Polytechnic Yola of Adamawa State. The coefficient of human resource utilization (HRU) and constant are found to be statistically significant as indicated by their probability values. Precisely, the significant level of human resource utilization (HRU) and constant obtained at $1 \%$ level (0.00) (0.00) respectively. The coefficient of explanatory variable of human resource utilization (HRU) is positively signed, indicating that $1 \%$ change in human resource utilization would increase the organizational growth and development by (1.271\%). The coefficient of determination $\mathrm{R}^{2}(0.916)$ shows that about $92 \%$ total variation in the dependent variable is explained by the change in the explanatory variable in the estimated model, while the remaining 8 percent has been captured by an error term. The Durbin Watson statistic (1.69) shows the absence of positive serial correlation.

Table 2 above presents the summary results for the impact of manpower training and development (MPTD) on employee performance. The coefficient of manpower training and development and constant are found to be statistically significant as indicated by their probability values. Precisely, the significance level of manpower training and development and constant are obtained at $1 \%$ level of significance $(0.000)$ and $(0.000)$ respectively. The coefficient of explanatory variable of leadership style is positively signed, indicating

\begin{tabular}{|l|l|l|l|l|}
\hline Variables & Coefficients & Std error & T-stat & Sig. \\
\hline Constant & 12.149 & 1.011 & 12.014 & 0.00 \\
\hline HRU & 1.271 & 0.154 & 8.211 & 0.00 \\
\hline R-squared & 0.916 & Adj. R-squared & 0.904 & \\
\hline Durbin Watson & 1.69 & F-statistic 143.013 & 0.000 & \\
\hline Source: Field Survey, 2018. & & \\
\hline
\end{tabular}

Table 1: Summary of simple regression result for hypothesis one.

\begin{tabular}{|l|l|l|l|l|}
\hline Variables & Coefficients & Std error & T-stat & Sig. \\
\hline Constant & 14.407 & 1.318 & 10.928 & 0.00 \\
\hline HRU & 0.080 & 0.018 & 4.497 & 0.000 \\
\hline R-squared & 0.532 & Adj. R-squared & 0.548 & \\
\hline Durbin Watson & 1.705 & & & \\
\hline Source: Field Survey, 2018. & & & \\
\hline
\end{tabular}

Table 2: Summary of simple regression result for hypothesis two. that $1 \%$ change in manpower training and development would increase the organizational growth of State Polytechnic Yola by (0.080) percent respectively. The coefficient of determination $\mathrm{R}^{2}(0.532)$ shows that about $53 \%$ total variation in the dependent variable is explained by the change in the explanatory variable in the estimated model, while the remaining $47 \%$ has been captured by an error term. The adjusted coefficient of determination (0.548) shows that after taking into account the loss in the degree of freedom, the model has a good fit. The Durbin Watson statistic (1.705) shows the absence of positive serial correlation.

Table 3 above presents the summary results for the factors militating against success in effective human resource management on organizational growth in State Polytechnic Yola. The coefficient of factors affecting human resource utilization (FAHRU) and constant are found to be statistically significant as indicated by their probability values. Precisely, the significance level of factors affecting human resource utilization (FAHRU) and constant are obtained at $1 \%$ level of significance (0.000) and (0.000) respectively. The coefficient of explanatory variable of organizational growth is positively signed, indicating that $1 \%$ change in factors affecting human resource utilization would increase the organizational growth by $(0.321)$ percent respectively. The coefficient of determination $\mathrm{R}^{2}(0.621)$ shows that about $62 \%$ total variation in the dependent variable is explained by the change in the explanatory variable in the estimated model, while the remaining $38 \%$ has been captured by an error term. The adjusted coefficient of determination (0.604) shows that after taking into account the loss in the degree of freedom, the model is not fit. The Durbin Watson statistic (1.71) shows the absence of positive correlation.

Table 4 above presents the summary results for the Impact of recruitment and selection in utilization of human resource utilization on organizational growth and development in State Polytechnic Yola, Adamawa State. The coefficient of human resource utilization and constant are found to be statistically significant as indicated by their probability values, while the coefficient of recruitment and selection of human resource utilization is found to be statistically insignificant. Precisely, the significance level of recruitment and selection in utilization of human resource and constant are obtained at $1 \%$ level of significance $(0.000)$ and $(0.000)$ respectively, while the significance level of human resource utilization is obtained at 10 percent level of significance. The coefficient of explanatory variable of human resource utilization (HRU) is positively signed, indicating that $1 \%$ change in HRU would increase the organizational performance by $(0.472)$ percent respectively, while the coefficient of recruitment and selection is (RS) negatively signed, indicating that $1 \%$ change in human resource

\begin{tabular}{|l|l|l|l|l|}
\hline Variables & Coefficients & Std error & T-stat & Sig. \\
\hline Constant & 0.197 & 0.0201 & 9.832 & 0.00 \\
\hline HRU & 0.321 & 0.039 & 8.177 & 0.000 \\
\hline R-squared & 0.621 & Adj. R-squared & 0.604 & \\
\hline Durbin Watson & 1.71 & & & \\
\hline Source: Field Survey, 2018. & & &
\end{tabular}

Source: Field Survey, 2018.

Table 3: Summary of simple regression result for hypothesis three.

\begin{tabular}{|l|l|l|l|l|}
\hline Variables & Coefficients & Std error & T-stat & Sig. \\
\hline Constant & 11.214 & 1.314 & 8.853 & 0.00 \\
\hline RS & -0.001 & 0.021 & -0.026 & 0.979 \\
\hline HRU & 0.472 & 0.072 & 6.556 & 6.556 \\
\hline R-squared & 0.750 & Adj. R-squared & 0.741 & 0.000 \\
\hline Durbin Watson & 1.143 & & & \\
\hline Source: Field Survey, 2018. & & \\
\hline
\end{tabular}

Table 4: Summary of multiple regression result for hypothesis four. 
utilization would decrease the organizational growth and development by $(0.001 \%)$. The coefficient of determination $\mathrm{R}^{2}(0.750)$ shows that about $75 \%$ total variation in the dependent variable is explained by the change in the explanatory variable in the estimated model, while the remaining $25 \%$ has been captured by an error term. The adjusted coefficient of determination (0.741) shows that after taking into account the loss in the degree of freedom, the model has a good fit. The Durbin Watson statistic (1.143) shows the presence of positive serial correlation.

Table 5 above presents the summary results for the impact of staff welfare/health safety of employee towards human resource utilization on growth and development of State Polytechnic Yola. The coefficient of staff welfare/health safety and constant are found to be statistically significant as indicated by their probability values. Precisely, the significance level of staff welfare/health safety and constant are obtained at $1 \%$ level of significance $(0.000)$ and $(0.000)$ respectively. The coefficient of explanatory variable of staff welfare/health safety is positively signed, indicating that $1 \%$ change in staff welfare/health safety would increase the organizational growth and development by 0.087 percent respectively. The coefficient of determination $\mathrm{R}^{2}(0.612)$ shows that about $61.2 \%$ total variation in the dependent variable is explained by the change in the explanatory variable in the estimated model, while the remaining $38.8 \%$ has been captured by an error term. The adjusted coefficient of determination (0.627) shows that after taking into account the loss in the degree of freedom, the model has a good fit. The Durbin Watson statistic (1.431) shows the absence of positive correlation.

\begin{tabular}{|l|l|l|l|l|}
\hline Variables & Coefficients & Std error & T-stat & Sig. \\
\hline Constant & 12.618 & 1.318 & 11.532 & 0.00 \\
\hline HRU & 0.087 & 0.023 & 6.197 & 0.000 \\
\hline R-squared & 0.612 & Adj. R-squared & 0.627 & \\
\hline Durbin Watson & & & & \\
\hline Source: Field Survey, 2018. & & & \\
\hline
\end{tabular}

Table 5: Summary of simple regression result for hypothesis five.

\section{Conclusion}

This study investigated impact of human resource resources utilization on organizational growth and development in State Polytechnic Yola, Adamawa State Nigeria. The study revealed that the coefficient of human resource utilization (HRU) and constant are found to be statistically significant as indicated by their probability values. Precisely, the significant level of human resource utilization (HRU) and constant obtained at $1 \%$ level $(0.00)(0.00)$ respectively. This shows that there is a significant relationship between employer/employee and organization achievement. The coefficient of explanatory variable of human resource utilization (HRU) is positively signed, indicating that $1 \%$ change in human resource utilization would increase the organizational growth and development by $(1.271 \%)$. The coefficient of manpower training and development and constant are found to be statistically significant as indicated by their probability values. Precisely, the significance level of manpower training and development and constant are obtained at $1 \%$ level of significance $(0.000)$ and $(0.000)$ respectively. The coefficient of explanatory variable of leadership style is positively signed, indicating that $1 \%$ change in manpower training and development would increase the organizational growth of State Polytechnic Yola by $(0.080)$ percent respectively. The coefficient of factors affecting human resource utilization (FAHRU) and constant are found to be statistically significant as indicated by their probability values. Precisely, the significance level of factors affecting human resource utilization (FAHRU) and constant are obtained at $1 \%$ level of significance (0.000) and (0.000) respectively. The coefficient of explanatory variable of organizational growth is positively signed, indicating that $1 \%$ change in factors affecting human resource utilization would increase the organizational growth by $(0.321)$ percent respectively.

The coefficient of human resource utilization and constant are found to be statistically significant as indicated by their probability values, while the coefficient of recruitment and selection of human resource utilization is found to be statistically insignificant. Precisely, the significance level of recruitment and selection in utilization of human resource and constant are obtained at $1 \%$ level of significance $(0.000)$ and $(0.000)$ respectively, while the significance level of human resource utilization is obtained at 10 percent level of significance. The coefficient of explanatory variable of human resource utilization (HRU) is positively signed, indicating that $1 \%$ change in HRU would increase the organizational performance by $(0.472)$ percent respectively, while the coefficient of recruitment and selection is (RS) negatively signed, indicating that $1 \%$ change in human resource utilization would decrease the organizational growth and development by $(0.001 \%)$. shows that there is significant relationship between recruitment and organizational achievement in State Polytechnic Yola. The coefficient of staff welfare/health safety and constant are found to be statistically significant as indicated by their probability values. Precisely, the significance level of staff welfare/health safety and constant are obtained at $1 \%$ level of significance $(0.000)$ and $(0.000)$ respectively. The coefficient of explanatory variable of staff welfare/health safety is positively signed, indicating that $1 \%$ change in staff welfare/health safety would increase the organizational growth and development by (0.087) percent respectively.

Finally, this result revealed that human resource utilization influences organizational growth and development in State Polytechnic Yola in Adamawa State.

Based on the findings of this study it is concluded that emphasis should be on recruitment/selection of qualified personnel. Also performance appraisal should be based on rewarding effective and productive personnel. Motivation should be encourage by management to a deserved personnel this is no doubt will enhance the performance of the organization. Government on the other hand should provide the enabling environment, provide the basic infrastructural such as water, road, educational materials, teaching aids, science laboratory etc. so as to improve the educational standard in an institution of learning.

The study recommends that recruitment and selection should be effectively done in order to maximize employee's productivity. The study recommended that staff training and development should be strengthened and encouraged. This can be done through the organization of workshops and seminars to enable the employees to have knowledge of their work and take advantage of it to boost their productivity. The study recommended that employee's performance appraisal should be taken seriously so as to boost their productivity. Finally, this study recommended the need for State Polytechnic Yola to focus attention on increasing human resource management practice especially human resource planning and staff training and development.

\section{References}

1. Susan M (2012) What is Human Resource Management.

2. Werner JM (2014) Empirical Research on Human Resource Management as a Production of Ideology. J Ideology, Power research \& Images of Work 2: 32-45. 
Citation: Francis F (2018) An Assessment of Human Resource Utilization on Organizational Growth and Development of Adamawa State Polytechnic Yola. Arts Social Sci J 9: 419. doi: 10.4172/2151-6200.1000419

3. Khalid K, Salim HM, Loke S, Khalid K (2011) Demographic Profiling on job Satisfaction in Malaysian Utility sector. Int J Academic Res 3: 192-198.

4. Moorhouse L, Cunningham $P$ (2010) Permanently in process: the intersection of migration, work identity and the reality of human resource development in the South African context. J Human Resource Development Int 13: 587-597.

5. Kaiser S (2011) Creating Balance? International Perspectives on the Work-Life Integration of Professionals. Berlin: Springer.

6. Jost JT, Nosek BA, Gosling SD (2008) Ideology: Its Resurgence in Social, Personality, and Political Psychology. Perspect Psychol Sci 3: 126-136.

7. Preuss L, Haunschild A, Matten D (2009) The Rise of CSR: Implications for HRM and Employee Representation. Int J Human Resource Management 20: 953-973.

8. Kenneth M (2009) Human Capital Development Crucial to Vision 20-2020. Business News.

9. Ogbodo CY (2007) Annals of Management Accounting: An Empirical Approach (1stedn), Awka: Rex Charles and Patrick Ltd.

10. Qureshi MT, Ramay IM (2006) Impact of Human Resource Management Practices on Organizational Performance in Pakistan, Muhammad Ali Jinnah University, Islamabad.

11. Chand M, Katou A (2007) The impact of HRM practices on organizational performance in the Indian hotel industry. Employee Relations 29: 576-594.

12. Bratton J, Gold J (2007) Human Resource Management: Theory and Practice (4thedn), Houndmills: Macmillan.

13. Pfeffer J (1994) Competitive advantage through people. Boston: Harvard Business School Press

14. Huselid MA, Jackson SE, Schuler RS (2007) Technical and strategic human resource management effectiveness as determinants of firm performance. Academy of Management J 40: 171-189.

15. Budd JW, Bhave D (2010) The Employment Relationship. In: Wilkinson A Redman T, Snell S, Bacon N (eds.) The SAGE Handbook of Human Resource Management Los Angeles: SAGE 51-70.
16. Mondy RW, Noe RM (2005) Human Resource Management (9thedn).

17. Ivancevich JM (2001) Human Resource Management (8thedn), McGraw-Hill: New York.

18. Mookherjee D (2005) Decentralization, Hierarchies and Incentives: A Mechanism Design Approach. J Economic Literature 44: 367-390.

19. Ojo O (2009) Impact assessment of corporate culture on employee job: J Business Intelligence 2: 389-370.

20. Peretomode V, Peretomode O (2001) Human Resource Management, Lagos Obaroh and Ogbinaka publishers limited.

21. Lillian K, Mathooko $\mathrm{H}$, Sitati N (2012) Procedural justice in performance evaluation: The role of instrumental and non-instrumental voice in performance appraisal discussions. J Management 21: 57-69.

22. Gallup P (2012) Employee engagement

23. Benner MJ, Tushman ML (2003) Exploitation, exploration, and process management: The productivity dilemma revisited. Academy of Management Review 28: 238-256.

24. Brown M, Heywood JD (2005) Performance Appraisal System: Determinants and Change. British J Industrial Relations 43: 659-679.

25. Golden TD, Veiga JF (2008) The impact of superior-subordinate relationships on the commitment, job satisfaction, and performance of virtual workers. Leadership Quarterly 19: 77-88

26. Werner JM, DeSimone RL (2006) Human Resource Development. Ohio Thomson South-Western.

27. Grant T (2008) Corporate Social Responsibility: A Necessity Not a Choice. Bangkok: Author.

28. Yamane T (1967) Statistic: An Introductory Analysis (2ndedn), New York Harper and Row.

29. Mugenda O, Mugenda A (2009) Research Methods, quantitative and qualitative approach. Nairobi: ACTS Press. 20. Noe RA, Hollenbeck, J.R.

30. Koch MJ, McGrath RG (1996) Improving Labor Productivity: Human Resource Management Policies do Matter, Strategic Management J 17: 335-354. 